\title{
Implementation of the Building Permit Policy in terms of Communication and Resources Aspects in Palu City
}

\author{
Nuraisyah $^{1}$, Syahir Natsir ${ }^{1}$, Nasir Mangngasing ${ }^{1}$, Daswati ${ }^{1}$ \\ ${ }^{1}$ Doctoral Program in Social Sciences, Postgraduate, Tadulako University, Indonesia
}

\begin{abstract}
This study aims to analyze the implementation of the Building Permit Policy in Palu City. This study looks specifically at the aspects of communication and resources. This type of sub-district is descriptive qualitative. The sub-district location determined by the subdistricter is Palu City. The informants are 9 people, namely those who understand, know, experience and understand what will be sub-districted, especially related to the policy of building permits in Palu City, such as the Palu City Spatial Planning and Land Office by extracting information through observations and interviews. The results showed that one of the reasons was due to the lack of socialization by the Palu City Spatial Planning and Land Planning (DPRP) officials. In fact, communication is crucial to success in implementing policies effectively. Human resources in terms of quality are adequate but in terms of quantity they are inadequate and facilities and infrastructure that can be used as operational tools are inadequate.
\end{abstract}

Keywords: Policy Implementation, Building Permit, Communication, Resources

Received: October 22, 2020

Received in Revised: October 30, 2020

Accepted: November 4, 2020

\section{Introduction}

The public policy process focuses on policy implementation which is a practical stage and is distinguished from policy formulation which can be viewed as a theoretical stage. Therefore, the implementation of public policies needs to be carried out by considering various factors so that the intended public policies can actually function as a tool to realize the desired expectations.

Public policy implementation is an effort to realize a decision or agreement that has been previously determined. Implementation is a very decisive stage in the policy process because without effective implementation, the decision of policy makers will not be successful (Pülzl $\&$ Treib, 2017). Policy implementation is an activity that is seen after there is valid direction of a policy which includes efforts to manage inputs to produce outputs or outcomes for society (Jordan, 1999; DeLeon \& DeLeon, 2002; V Gedung, 2017).

The implementation process will only begin when the goals and objectives have been set, then the activity program has been structured and funds are ready for the implementation process and has been channeled to achieve the desired target or policy objective. Policy usually contains a program to achieve goals, values that are carried out through directed actions (Van Meter \& Van Horn, 1975). If a program or policy has been made, the program must be carried out by the mobiliastor or officials concerned. A policy that has been formulated certainly has goals or targets to be achieved (Houck, 2002; Martin \& Martin, 2005; Amir, 2020).

If we take a closer look at the implementation of the building permit policy in Palu City from the perspective of good governance, of course it still leaves various kinds of problems and question marks. Therefore, regarding the implementation of the building permit policy, the Government of Palu City needs to get special attention, because if it is not regulated from 
now on, it will have an impact on the unfocused development of Palu City and will then cause difficulties in urban structuring in the future. As for the obstacles and problems that arise, namely there are still buildings that were erected without having a building permit due to the large area and public awareness and knowledge of the law is not so high.

Apart from the lack of information obtained by the public regarding permits to build buildings in Palu City, this is of course a very urgent problem, because if you do not have a building permit, the construction of the building will not get recognition from the government and it does not rule out the possibility of building status. it is considered an illegal building because it does not have complete documents. Another problem that makes people reluctant to apply for building permits is because there is still a growing perception among the community that the process of obtaining a building permit is too bureaucratic. Therefore, to break the stigma that was already developing in the community, the Palu City Spatial Planning and Land Office issued a policy of whitening building permits.

The implementation of the Development Licensing Policy has been carried out in previous sub-district, namely the Innocent sub-district (2016) and the Baleke (2016) sub-district which shows that there are obstacles infield implementation in the form of negative impacts felt by citizens of the City due to development which deserves attention by the government, the lack of communication that exists between program implementers with the target group, even though it has been done. Both studies use Edward III (1980) theory. The purpose of this study is to analyze the Implementation of Building Permit Policy in Palu City. This sub-district looks specifically at the aspects of communication and resources.

\section{Methods}

The type of sub-district used as a reflection of the basic sub-district design in order to obtain data is a type of qualitative descriptive sub-district. The sub-district location determined by the sub-districter is Palu City. The informants are 9 people, namely those who understand, know, experience and understand about what will be sub-districted, especially related to the policy of building permits in Palu City such as the Palu City Spatial Planning and Land Office, which in this case is expected to coordinate with the Investment Service and OneStop Integrated Service for Palu City. Data collection techniques through observation and interviews. Data analysis, namely the Interactive Model. This interactive model consists of three main things, namely data condensation, data presentation, and conclusion/verification.

\section{Results and Discussion}

\section{Policy implementation is seen from the communication aspect}

Implementation is a stage of the policy-making process in accordance with the objectives. This means that policy implementation is based on policy formulations that have been carried out and will be implemented. Whether a policy runs or not depends on the implementers in carrying out their duties and responsibilities, whether it runs effectively or not. If the implementation is not implemented properly it will cause failure. One aspect that supports policy implementation is communication, therefore, before implementing a policy, socialization is first carried out through communication channels either directly or through media tools. Socialization is a process of how to introduce a system to someone and how that person determines their responses and reactions. Socialization is determined by the social, economic and cultural environment in which the individual is located, but it is also determined by the interaction of experiences and personalities (Sutaryo, 2004). Coordination between implementing agencies must be in accordance with applicable procedural provisions so that the building permit policy in Palu City can be carried out accurately and consistently, which refers to coordination between organizations at the same level, for example the Palu 
City Spatial Planning and Land Office and the Investment Service. and One Stop Services for the City of Palu. In addition, there is communication in the form of socialization carried out by policy implementers to the community (target group).

Observing Sutaryo's opinion proves that before the policy was implemented, socialization was carried out through communication in order to create interactions with one another and to understand each other's contents of the policy. Communication, meaning that the implementers convey information to the communicant. Edward III (1980) explains that policy communication means the process of delivering policy information from policy makers to policy implementers. Policy communication has several dimensions, including dimensions of transformation, clarity and consistency.

The transformation dimension requires that public policies be transformed to implementers, target groups and other parties related to the policy. This means that policies related to building permits need to be transformed to policy users, namely the applicant community, either directly or indirectly. To transform to the applicant the implementers communicate by socializing to the public about the importance of having a Community Building Permit as stated by Lasswell's paradigm (1948) in his work "The Structure and Function of Communication in Society" simply the communication process is the communicator to form (encode) message and convey it through a certain channel to the recipient which causes certain effects.

Interpret the opinion of Edward III (1980) and Lasweel (1948), that the success of implementing policies is largely determined by the communication between the implementers and the policy users. Efforts made by the government to transform policies are communicating through channels such as newspapers, television, internet, banners and so on.

Listening to the informant's opinion, it turns out that the government is conducting socialization by gathering the village chiefs and through media tools, namely newspapers and the internet, but this is not sufficient, therefore implementers must have other strategies so that the public understands the process of issuing building permits according to the rules set by the government. As for the suggestion put forward by the informant that another strategy is needed, namely coordinating with other parties, it turns out that the government has collaborated with the Investment Service and One-Stop Integrated Services.

The results of the interviews proved that information was not always effectively transferred to the public, especially online, because not all people were active and mastered the media (HP), not to mention the inadequate internet network in every region. The existence of these obstacles so that people still do not understand that the building permit (IMB) service can be served through an information system or online, no longer visiting the office.

The results of the interviews proved that government officials had carried out socialization, but it seemed ineffective because the community did not understand the existence of services via the internet or WA. This means that the implementor of transferring policies by conducting outreach to the public has not been effective. Because through an intermediary, namely the Head of the Village, it is evident that the officials provide information that the socialization and coordination between organizations has been going well, it's just that it seems ineffective, because the authorities do not communicate directly with the community, even though communication is expected to establish communication with program implementers with target groups.

The results of the sub-districter's interviews with the Head of the Taipa Urban Village and the Head of Government and Trantib of Tondo Village prove that only a small proportion of the community has a building permit (IMB) because they do not understand the importance of 
building permits, meaning that communication with the community about the importance of building permits has not been created effectively, therefore it is necessary to conduct socialization without going through intermediaries. Through the online system or WA, it can help the community to arrange building permits, it's just that most people don't have internet access, so not all people who have houses to live in have building permits.

The opinion of the Head of Lambara Urban Village above proves that the socialization of the importance of the IMB in the Lambara Village area has not been carried out optimally. According to the village head, to conduct socialization to the community, of course, requires a budget at least for consumption, so that the village heads do not carry out the appeal from the Spatial Planning government, besides that the village heads think that it is not their authority to carry out the socialization because it is technical. Policy implementation through communication by transferring policies that must be implemented and socialization has not been effective, it is proven that there are still people who do not understand the procedures for building construction permits (IMB) services both directly and indirectly. and the impression is that the community is only limited to understanding if they directly visit the One-Stop Integrated Service Office.

The results of the interview proved that transforming policies to the community was not optimal if it was socialized through the sub-district without budget support, because the socialization would invite the public and require consumption funds and so on. This means that socialization is only limited to providing understanding to the sub-district, not maximally reaching the community. Edward III (1980) states that clarity requires that policies transmitted to implementers, target groups, and other parties with direct or indirect interests in policy can be received clearly so that among them know what is the intent, purpose and target and substance. of these public policies. If it is not clear, they will not know what should be prepared and implemented so that policy objectives can be achieved effectively and efficiently, such as the socialization of the IMB to the arrangement and issuance of the IMB, it is hoped that the applicant can understand the requirements that must be completed for the issuance of the IMB and understand the importance of having IMB.

Looking back at the views of the two communities proves that the community in principle does not understand the importance of a building permit (IMB) if they want to build, so the community is calm to build, especially since the Kelurahan government does not take warnings and actions according to applicable regulations.

The results of the interviews prove that the government has not implemented socialization about the importance of the IMB and there has been no strict sanction given to the community if they do not have an IMB. The community considers that the IMB only applies to developments in the category of large or multi-story houses. If the construction of a residential house does not need an IMB.

The results of interviews from the implementors of the Spatial Planning and Land Office, it can be seen that the socialization of the IMB has not been carried out effectively, because the socialization is simply inviting the village heads with the aim of the village heads who will conduct socialization to the community in each village. But in reality, there are some Lurahs who do not do it because he feels that it is not his authority and does not really understand technically and there is no budget for socialization. On this basis, the general public thinks that socialization has not been implemented effectively, but socialization can also be done through social media, namely television, internet and Baleho. It's just that the socialization carried out by the government has not fully understood the use of the on line system. 
The service system for issuing certificates for people who are in the modern category who understands IT really accepts the existence of an on line system, but people who do not understand IT certainly do not accept it, so the sub-districters conclude that policy implementation is seen from the aspect of communication by transforming policies to the public by using representation from the Kelurahan and the modern information system has not been effective. Information from the Spatial Planning and Land Office calls on the public to have an understanding that the obligation for the community to build in an area must apply to DPM \& PTSP, because we all already feel that building in a prohibited area then the community builds will have an impact on the future of that community itself, such as the disaster that hit Palu was a tsunami and the liquefaction of all buildings that were 100 meters from the shoreline were completely swallowed up by the tsunami. This means that every community who comes to apply for an application is sought to be accepted in a friendly, fast and precise manner to convey matters relating to the service procedure for issuing building permits in a clear and consistent manner, regardless of or discriminating against the applicant. The results of the sub-district prove that administrative services for IMB issuance are in accordance with predetermined procedures, because the implementor seeks to provide services in accordance with those stated in Government Regulation Number 10 of 2012, Chapter II Article 2 states that the issuance of IMB is carried out based on the principle of simple, easy and applicable procedures. Fast, affordable and on-time service.

Observing the opinions of informants from both the public and officials from the Spatial Planning and Land Office proves that the factor inhibiting the implementation of the IMB issuance policy is that there is no public understanding of the IMB service procedure, but the government has carried out socialization through newspapers, banners and the internet, but the level the applicant's understanding of using the internet is still far from what is expected. Even the Kelurahan is not ready to conduct the socialization, but in general the sub-district has been invited and given an understanding so that the Kelurahan should immediately conduct socialization. In fact, the recognition from the community has not been effective in the socialization by the government.

Based on the results of sub-district conducted by sub-districters, that the explanation of the principles, purposes and objectives of the building permit above, is still very far from what was expected, such as there are still people who build not according to the designation of building construction permits (IMB), and some even just want to build so that it does not match the building's demarcation line. One of the reasons is due to the lack of socialization by the Palu City Spatial Planning and Land Planning (DPRP) apparatus. In fact, communication is crucial to success in implementing policies effectively. Communication in the form of socialization can be carried out directly or indirectly to the public regarding the Palu City Regional Government Regulation Number 10 of 2012 concerning Building Construction Permits because the regulation describes benefits of having a Building Construction Permit. If this has not been carried out continuously, it will result in the community not understanding the importance of building permits (IMB), and not knowing what the aims, objectives and targets are and the substance of the building permit (IMB) policy. can be achieved effectively and efficiently.

\section{Policy Implementation Seen from the Resources Aspect}

Human resources (HR) are the main strategic contributors to all organizational activities. Therefore, every organization that wants to develop, the organization must manage and develop its human resources properly. Torang (2014), like the Spatial Planning and Land Office, is an organization that assists the City government in controlling building construction and non-building construction, because it requires adequate resources. Edward 
III (1980) argues that the resource factor has an important role in policy implementation. Even Edward III (1980) makes it clear that however, the policy implementer has explained to the public and is consistent with the rules, but without the support of human resources (human and budget), the policy faces obstacles to achieving its goals effectively.

The resources in question are human resources, financial resources, and equipment resources (buildings, land, and other spare parts needed in implementing policies, however, human resources are one of the determinants of success and failure in achieving the success of an organization. However, the equipment or infrastructure is ready without human resources, the facilities and infrastructure resources do not mean anything. The Spatial Planning and Land Office certainly expects human resources who have the ability and adequate skills to carry out their duties and functions properly, especially in spatial planning. and land in Palu City, it is better to conduct socialization to the maximum. As explained by Edward III (1980), that human resources are responsible for implementing policies. The human resources in question are none other than the employees of the Palu City Spatial Planning and Land Affairs Office. 16 people $\mathrm{g}$ who hold structural positions and are added with a staff of 25 people. Edwar III is of the opinion that but the implementor has communicated well, but it is not supported by human resources both in terms of quantity and quality, so the implementation of the policy faces a barrier.

To anticipate the public's lack of understanding about the IMB, human resources as far as possible have the knowledge and skills in carrying out their duties and functions as administrative and technical personnel, are expected to have experience.

The results of interviews from informants proved that the services provided to the community related to building permits, the government administratively were able to manage them well. However, from a technical point of view, it still requires human resources who can provide community satisfaction. The community really needs fast, precise and fair services, so that the growing issue is that the IMB management service is difficult. This requires human resources capable of continuous socialization.

The results of the interviews proved that the human resources and budgetary resources at the Palu City Spatial Planning and Land Affairs Office were inadequate. However, according to the fact that it can create coordination between organizations, namely the sub-district, but the IMB policy has not been maximally realized, even though information and procedures for building permits services can be well known to the public. However, due to inadequate budget resources, the human resources of the Land and Arrangement Service who control their duties and functions have not been maximally implemented, because the community always thinks that the procedure for building permits is difficult to administer.

Observing the opinion of informants from government elements, it is evident that the human resources of the Palu City Spatial Planning and Land Office are adequate, both in terms of quality and quantity, it's just that the resources of the facilities and budget resources are insufficient. In addition to human resources and infrastructure to streamline the implementation of policies that can support is budget resources. Edward III (1980) said that the limited available budget causes the limited quality of public services that must be provided to the public. The opinion of Edward III (1980) proves that the sufficiency of human resources, both in terms of quantity and quality, is inadequate if it is not supported by budgetary resources, it will have an impact on the implementation of policies to be implemented. The reason, according to Edwar III, was that policy actors were unable to carry out their duties and functions optimally and they did not receive the incentives as expected, causing the failure of program implementation. 
Human resources in the Department of Land and Administration of Palu City in terms of quality are adequate, but in terms of quantity it still needs to be improved, the reason is that non-PNS staff or employees still need to improve quality and quantity, especially in the field of IT or information and information systems, as well as sources power in terms of quantity is still necessary in order to provide services in all sub-districts and villages in Palu City.

The results showed that in Palu City, some people still do not have the awareness to have a building permit (IMB), because people sometimes think that the process of obtaining a building permit is rather difficult and convoluted, even though the One-Stop City Investment and Integrated Service Agency The hammer always provides services in accordance with predetermined procedures. This is the result if the lack of direct socialization is aimed at the community because they do not know the service procedures that will be received if they carry out building construction permits (IMB).

Observing the results of interviews sourced from informants that employees of the Palu City Spatial Planning and Land Office prove that human resources, budget resources, facilities and infrastructure resources as well as information and authority resources are expected to be fulfilled in implementing public policy. Edward III (1980) limited budget resources cause the quality of public services is also limited. This means that policy actors cannot carry out their duties and functions optimally and they do not get incentives, it will affect the achievement of goals, namely increasing public participation in ownership of building construction permits (IMB) in accordance with applicable regulations, namely every community who owns a building in the form of a building must have a building permit. building (IMB).

Based on the results of interviews obtained from informants, that the officials of Tondo Village have made efforts to continue to report related violations committed by the community. In addition, the Kelurahan always collaborates with the Spatial Planning Office, namely by monitoring the environment of each Kelurahan. It was proven that the Tondo Urban Village gave a warning to the people who were under construction if they did not have a building construction permit (IMB), but the community always ignored and tended to not really care, even though government officials had often made direct deliverables.

The results of the sub-district prove that the policy regarding building permits (IMB) has been implemented in collaboration with related parties, but the policy to be implemented still faces a barrier, namely that the community is not aware of the importance of having a building permit (IMB), but the Kelurahan government says well still the public takes it not seriously

Observing information from informants proves that the human resources of the Spatial Planning and Land Management Service have not maximally carried out their duties according to the needs in the field, as many people still do not have building permits (IMB), for various reasons including not knowing, lazy take care because of the many requirements that must be fulfilled not to mention the other costs that must be paid. However, human resources have coordinated between the government at the sub-district level, however implementing the building permit (IMB) policy is not yet adequate.

Edward III (1980) explains that limited resource resources result in detrimental to the implementation of accountability, and do not support efficiency and do not encourage the motivation of actors in implementing policies. Likewise, information resources and authority strongly support policy implementation as described by Edward III (1980) so that policy implementers do not make a mistake in interpreting how to implement or implement the policy. This means that the implementor is not wrong in providing understanding and information to the community. Therefore accurate information is needed in carrying out the 
task. Herein lies the importance of authority, especially ensuring and ensuring that the policies implemented are in accordance with predetermined procedures.

The results of field observations on February 11, 2020, that all field officers were always accompanied by a letter of assignment and used identification. This means that field officers have authority from the agency to carry out tasks, such as site surveys, site measurements and bring information to applicants. This means that resources are critical to policy implementation, because without resources in implementing public policies, it is difficult to achieve success. So whether or not it fails to implement the policy depends on the resources owned by the Palu City Spatial Planning and Land Office. The resources in question are human resources, budget resources, facilities and information resources and authorities. Edward III (1980) said that without these four resources, policy implementation would not be effective. The results showed that human resources in terms of quality were adequate but in terms of the quantity they were not sufficient as well as facilities and infrastructure that could be used as operational tools were inadequate at the Department of Spatial Planning and Land Affairs in Palu City.

\section{Conclusion}

communication to socialize the IMB management has not been implemented optimally, the quality of human resources supports it, but in terms of quantity and budget resources and facilities are inadequate. Externally, it should be maximally socialized about IMB issuance services at the village and sub-district levels. In terms of human resources, it is necessary to increase personnel or staff to collect data and supervise developments in Palu City, especially residential houses.

\section{References}

Amir, A. (2020). Public Policy Implementation: Study on Educational Budgeting of Palopo. Journal La Sociale, 1(1), 5-11.

Baleke. (2016). Implementasi Kebijakan Pelayanan Izin Mendirikan Bangunan (IMB) Di Kabupaten Nunukan. Thesis, Universitas Terbuka.

DeLeon, P., \& DeLeon, L. (2002). What ever happened to policy implementation? An alternative approach. Journal of public administration sub-district and theory, 12(4), 467-492.

Edward III, G. C. (1980). Implementing Public Policy, Congressional Quartley Inc., Washington.

Houck, O. A. (2002). The clean water act TMDL program: Law, policy, and implementation. Environmental Law Institute.

Inosensius, P. N. (2016). Implementasi Kebijakan Pengendalian Pembangunan Hotel Di Kota Yogyakarta (Studi Deskriptif kualitatif Peraturan Walikota Yogyakarta No. 77 Tahun 2013). Sekolah Tinggi Pembangunan Masyarakat Desa.

Jordan, A. (1999). The implementation of EU environmental policy; a policy problem without a political solution?. Environment and Planning C: Government and Policy, 17(1), 69-90.

Lasswell, H. D. (1948). The structure and function of communication in society. The communication of ideas, 37(1), 136-139.

Martin, P. P., \& Martin, P. P. (2005). Social Security: A program and policy history. Soc. Sec. Bull., 66, 1. 
Pülzl, H., \& Treib, O. (2017). Implementing public policy. In Handbook of public policy analysis (pp. 115-134). Routledge.

Sutaryo, (2004). Dasar-Dasar Sosialisasi. Jakarta: Rajawali Press.

Torang, S. (2014). Organization and Management. Bandung: Alfabeta.

Van Meter, D. S., \& Van Horn, C. E. (1975). The policy implementation process: A conceptual framework. Administration \& Society, 6(4), 445-488.

Vedung, E. (2017). Public policy and program evaluation. Routledge. 